University of Nebraska - Lincoln

DigitalCommons@University of Nebraska - Lincoln

Faculty Publications: Department of Entomology

$1-1970$

\title{
Seasonal Abundance and Distribution of Benthic Fauna within a Pond
}

Ellis L. Matheny

University of Tennessee

E. A. Heinrichs

University of Tennessee, eheinrichs2@unl.edu

Follow this and additional works at: https://digitalcommons.unl.edu/entomologyfacpub

Part of the Entomology Commons

Matheny, Ellis L. and Heinrichs, E. A., "Seasonal Abundance and Distribution of Benthic Fauna within a Pond" (1970). Faculty Publications: Department of Entomology. 894.

https://digitalcommons.unl.edu/entomologyfacpub/894

This Article is brought to you for free and open access by the Entomology, Department of at DigitalCommons@University of Nebraska - Lincoln. It has been accepted for inclusion in Faculty Publications: Department of Entomology by an authorized administrator of DigitalCommons@University of Nebraska - Lincoln. 
Published in Annals of the Entomological Society of America 63:1 (January 1970), pp. 31-34; doi: 10.1093/ aesa/63.1.31

Copyright (C) 1970 Entomological Society of America. Published by Oxford University Press. Used by permission.

Submitted March 7, 1969; published January 15, 1970.

\title{
Seasonal Abundance and Distribution of Benthic Fauna within a Pond
}

\author{
Ellis L. Matheny and E. A. Heinrichs
}

Department of Agricultural Biology, University of Tennessee, Knoxville, Tennessee, USA

\begin{abstract}
A Tennessee pond was sampled weekly from June 18 to August 20, 1968, to determine quantitative differences among benthic organisms in sampling depths and dates. Annelids (Oligochaeta), Chironomidae larvae, and Chaoboridae larvae were the dominant organisms collected. Preferred depths existed for each group of organisms. Chaoboridae and Chironomidae exhibited distinct seasonal variations in numbers, with the population decreasing throughout the summer. Chaoboridae were the most and Chironomidae the least numerous of the 3 groups.

Invertebrate organisms play a major role in the food chain of a pond, as the weight of fish produced is limited by the amount of food available to them. Limnological conditions determine the abundance and distribution of an organism within a body of water. Bottom fauna are often restricted to shallow portions of a pond because of a greater abundance of oxygen there in summer (Wallen 1955). Eggleton (1934) found that benthic fauna in Michigan lakes was not uniformly distributed over the bottom. He concluded that the fauna varied qualitatively and quantitatively with seasons, depth, and chemical water condition. The purpose of our study was to determine quantitative differences among various groups of benthic fauna in dates and depths sampled.
\end{abstract}

\section{Procedure}

The pond was situated on University of Tennessee, Atomic Energy Commission land near Oak Ridge, Tennessee. The watershed consisted of a corn field and pasture land. Surface 
area was ca. 0.5 acre and the maximum depth was $9 \mathrm{ft}$. The bottom sloped gradually on all sides and formed a bowl-like depression. Previous to the study, the pond was renovated with rotenone and restocked with bluegill, Lepomis macrochirus Kafinesque, and largemouth bass, Microptcrus salmoidcs Lacepede.

Sampling was conducted during a 10-week period (June 18-Aug. 20, 1968). A total of 240 samples was taken along alternating, weekly transections at 3-, 5-, 7-, and 9-ft depths with a $6 \times 6$-in. Ekman dredge as described by Welch (1948). Bottom fauna were collected by washing the mud through a 30-mesh sieve. The organisms were preserved in $70 \%$ alcohol and returned to the laboratory for counting. Additional samples were taken June 6, 1969 , to determine the number of each species at each of the 4 depths.

Air and water temperatures were recorded on each sampling date with a hydrographic thermistor thermometer. Water samples for chemical determinations were taken monthly. These samples were collected with a 1-liter Kemmerrer nomnetallic water sampler, and all subsequent tests were performed in accordance with Hach's "Procedures for Water and Sewage Analysis" (Hach Chemical Co., Ames, Iowa).

\section{Results and Discussion}

\section{Physico-chemical Analysis}

Water quality, as a result of various factors, may change rapidly within a short period (Schultz 1952, Dineen 1953). Therefore, our study was not an attempt to obtain data on the complex relationships among the various physical and chemical properties of pond water, as sampling was conducted on a periodic basis.

Water temperatures ranged from $21.7^{\circ} \mathrm{C}$ in June to $28.9^{\circ} \mathrm{C}$ in August. The pond stratified both thermally and chemically during the summer months, but because of its slight depth, changes occurred rapidly. During this period, surface and bottom water temperatures were often the same (Table 1). Secchi disk readings (measuring the limit of transparency) ranged from 0.5 to $2.5 \mathrm{ft}$.

Table 1. Air and water temperatures in ${ }^{\circ} \mathrm{C}$ at a pond near Oak Ridge, Tennessee, on various dates (1968)

\begin{tabular}{|c|c|c|c|c|c|c|c|c|c|c|}
\hline & \multicolumn{2}{|c|}{ June } & \multicolumn{5}{|c|}{ July } & \multicolumn{3}{|c|}{ August } \\
\hline & 18 & 24 & 2 & 9 & 16 & 23 & 30 & 6 & 13 & 20 \\
\hline Air & 24.4 & 28.9 & 27.2 & 22.2 & 28.3 & 25.6 & 22.8 & 27.8 & 23.9 & 25.6 \\
\hline Surface & 25.0 & 28.3 & 28.3 & 26.7 & 28.3 & 28.3 & 27.2 & 28.9 & 27.8 & 28.9 \\
\hline $1 \mathrm{ft}$ & 25.0 & 28.3 & 28.3 & 26.7 & 28.3 & 28.3 & 27.2 & 28.9 & 27.8 & 28.9 \\
\hline $2 \mathrm{ft}$ & 25.0 & 28.3 & 28.3 & 26.7 & 28.3 & 28.3 & 27.2 & 28.9 & 27.8 & 28.9 \\
\hline $3 \mathrm{ft}$ & 25.0 & 28.3 & 28.3 & 26.7 & 28.3 & 28.3 & 27.2 & 28.9 & 27.8 & 28.9 \\
\hline $4 \mathrm{ft}$ & 25.0 & 28.3 & 28.3 & 26.7 & 28.3 & 28.3 & 27.2 & 28.9 & 27.8 & 28.9 \\
\hline $5 \mathrm{ft}$ & 25.0 & 27.2 & 27.2 & 26.7 & 28.3 & 28.3 & 27.2 & 28.3 & 27.8 & 28.9 \\
\hline $6 \mathrm{ft}$ & 25.0 & 25.6 & 26.1 & 26.7 & 27.8 & 28.3 & 27.2 & 27.8 & 27.8 & 28.3 \\
\hline $7 \mathrm{ft}$ & 25.0 & 24.4 & 25.0 & 25.6 & 26.7 & 27.2 & 27.2 & 26.7 & 27.8 & 28.3 \\
\hline $8 \mathrm{ft}$ & 21.7 & 22.2 & 23.9 & 25.0 & 26.1 & 26.1 & 27.2 & 26.1 & 27.8 & 27.8 \\
\hline $9 \mathrm{ft}$ & 21.7 & 22.2 & 23.9 & - & - & - & - & - & - & - \\
\hline
\end{tabular}


Dissolved oxygen concentration ranged between 5.9 and $9.2 \mathrm{ppm}$ with the exception of a deep-water sample taken in June, when the oxygen content fell to $0.1 \mathrm{ppm}$. At this time the free carbon dioxide content rose sharply to over $100 \mathrm{ppm}$. In all other samples taken, free carbon dioxide content ranged from less than 1.0 to $2.0 \mathrm{ppm}$, and $\mathrm{pH}$ varied from 6.9 to 8.9 during the sampling period.

\section{Benthic Fauna}

Difficulty is encountered when attempting to identify large numbers of specimens as are collected in a study of this nature. Therefore, data concerning number of species at various depths is available for only 1 sampling date. Table 2 shows the species and the depth at which they were collected. Chaoboridae species (Sayomyia punctipcnnis Say and S. albata Johnson) were collected only at 7- and 9-ft depths. Because of the large numbers of chaoborids and difficulty of making taxonomic determinations of their immatures, numbers were not determined for the sampling date.

\begin{tabular}{|c|c|c|}
\hline Depth & Organism & Mean no. collected $/ \mathrm{m}^{2}$ \\
\hline \multirow[t]{8}{*}{$3 \mathrm{ft}$} & Chironomidae & \\
\hline & Chironomus attenuatus (Walker) & 15 \\
\hline & Polypedilum sp. & 418 \\
\hline & Procladius prob. culiciformis (L.) & 346 \\
\hline & Clinotanypus sp. & 7 \\
\hline & Cryptochironomus prob. digitatus Malloch & 7 \\
\hline & Annelida & \\
\hline & Oligochaeta (prob. Limnodrilus sp.) & 339 \\
\hline \multirow[t]{8}{*}{$5 \mathrm{ft}$} & Chironomidae & \\
\hline & Chironomus attenuatus & 51 \\
\hline & Polypedilum sp. & 109 \\
\hline & Procladius prob. culiciformis & 57 \\
\hline & Cryptochironomus prob. digitatus Malloch & 57 \\
\hline & Tanypus neopunctipennis Sublette & 7 \\
\hline & Annelida & \\
\hline & Oligochaeta (prob. Limnodrilus sp.) & 375 \\
\hline \multirow[t]{6}{*}{$7 \mathrm{ft}$} & Chironomidae & \\
\hline & Chironomus attenuatus & 87 \\
\hline & Polypedilum sp. & 7 \\
\hline & Procladius prob. culiciformis & 29 \\
\hline & Annelida & \\
\hline & Oligochaeta (prob. Limnodrilus sp.) & 548 \\
\hline
\end{tabular}

Annelids (Oligochaeta), Chironomidae larvae, and Chaoboridae larvae were the dominant organisms collected. A few Libellulidae and Ceratopogonidae immatures were collected but were so sparse that they are not included in this discussion. 


\section{Distribution in Pond}

Annelids were significantly more abundant at $7 \mathrm{ft}$ (Table 3) than at other depths. There was no significant difference between 3- and 5-ft depths, but the number at $9 \mathrm{ft}$ was significantly lower (less than $0.5 / \mathrm{m}^{2}$ ).

\begin{tabular}{|c|c|c|c|}
\hline Depths sampled & Annelids ${ }^{b}$ & Chironomidae & Chaoboridae \\
\hline $3 \mathrm{ft}$ & $755 \mathrm{~b}$ & $168 \mathrm{c}$ & $0 \mathrm{c}$ \\
\hline $5 \mathrm{ft}$ & $605 \mathrm{~b}$ & $380 \mathrm{ab}$ & $0 \mathrm{c}$ \\
\hline $7 \mathrm{ft}$ & $1,092 \mathrm{a}$ & $415 \mathrm{a}$ & $3,660 \mathrm{~b}$ \\
\hline $9 \mathrm{ft}$ & $0 \mathrm{c}$ & $0 \mathrm{~d}$ & $15,616 \mathrm{a}$ \\
\hline
\end{tabular}

aData transformed to $(X+1)$

bAny 2 means followed by the same letter do not differ significantly as determined by Duncan's multiple range test at the $1 \%$ level of probability.

Chironomidae were more numerous at the 7-and 5- $\mathrm{ft}$ depths than at 3 or $9 \mathrm{ft}$. Only a few (less than $0.5 / \mathrm{m}^{2}$ ) were found at $9 \mathrm{ft}$.

Chaoboridae differed from the annelids and Chironomidae in being most numerous at $9 \mathrm{ft}$, with less than $0.5 / \mathrm{m}^{2}$ being found at 3 and $5 \mathrm{ft}$. Thus, Chaoboridae prefer $9 \mathrm{ft}-$, annelids $7 \mathrm{ft}-$, and Chironomidae the 5- through 7-ft depths.

\section{Seasonal Abundance}

The annelid population varied little throughout the summer (Table 4). However, on Aug. 20 the population was highest. The population on this date was significantly higher than on July 9 and 16. In June and July greater numbers were found at $7 \mathrm{ft}$. In August annelids were most abundant at 3-ft depths.

Chironomidae larvae were significantly more abundant in June than on any following dates. There was a rapid decrease from June 24 to July 2. During this period many pupal exuviae were seen on the surface, indicating that emergence had occurred. There followed a gradual decrease in number, reaching a low on Aug. 20. They were most abundant at $7 \mathrm{ft}$ in early summer. Throughout the remainder of the sampling period there was little difference among the 3-, 5-. and 7-ft depths.

Chaohoridae larvae were most abundant in June, their numbers decreasing rapidly through July 9. Apparently emergence occurred, as many pupal exuviae were observed on the surface. The population remained fairly constant from July 9 to July 30 but then declined rapidly and reached a low at the end of the sampling period.

The average number of Chaoboridae $\left(9,368 / \mathrm{m}^{2}\right)$ was significantly greater than of annelids $\left(613 / \mathrm{m}^{2}\right)$ and Chironomidae $\left(240 / \mathrm{m}^{2}\right)$ for the entire sampling period. However, Chaoboridae are much smaller than either annelids or Chironomidae, and figures for total biomass would be considerably different than total numbers. The importance of the organisms in the diet of the fish was not determined. 
Matheny and Heinrichs, Annals of the Entomological Society of America 63 (1970)

Table 4. Mean number of organisms per square meter of bottom surface in pond ${ }^{a}(1968)$

\begin{tabular}{|c|c|c|c|c|c|}
\hline \multirow[b]{2}{*}{ Date } & \multicolumn{4}{|c|}{ Depth (ft) } & \multirow[b]{2}{*}{ Mean ${ }^{b}$} \\
\hline & 3 & 5 & 7 & 9 & \\
\hline \multicolumn{6}{|c|}{ Annelids } \\
\hline June 18 & 570 & 534 & 1,039 & 0 & $714 \mathrm{ab}$ \\
\hline 24 & 317 & 1,061 & 1,436 & 0 & $938 \mathrm{ab}$ \\
\hline July 2 & 360 & 649 & 1,313 & 0 & $774 \mathrm{ab}$ \\
\hline 9 & 411 & 556 & 866 & 0 & $611 b$ \\
\hline 16 & 354 & 375 & 1,198 & 0 & $642 b$ \\
\hline 23 & 289 & 657 & 1,407 & 0 & $784 \mathrm{ab}$ \\
\hline 30 & 743 & 613 & 924 & 0 & $760 \mathrm{ab}$ \\
\hline Aug. 6 & 1356 & 411 & 981 & 0 & $916 \mathrm{ab}$ \\
\hline 13 & 1,529 & 419 & 916 & 0 & $955 \mathrm{ab}$ \\
\hline 20 & 1,623 & 779 & 837 & 0 & $1,079 \mathrm{a}$ \\
\hline Total & 7,552 & 6,054 & 10,917 & & \\
\hline \multicolumn{6}{|c|}{ Chironomidae } \\
\hline June 18 & 173 & 823 & 1,717 & 0 & $904 a$ \\
\hline 24 & 209 & 844 & 1,147 & 0 & 733 a \\
\hline July 2 & 145 & 592 & 476 & 0 & $404 \mathrm{~b}$ \\
\hline 9 & 123 & 368 & 224 & 0 & $238 \mathrm{bc}$ \\
\hline 16 & 246 & 318 & 231 & 0 & $264 \mathrm{~b}$ \\
\hline 23 & 346 & 202 & 101 & 0 & $216 \mathrm{bc}$ \\
\hline 30 & 123 & 238 & 159 & 0 & $173 \mathrm{c}$ \\
\hline Aug. 6 & 101 & 159 & 65 & 0 & $108 \mathrm{c}$ \\
\hline 13 & 130 & 123 & 7 & 0 & $87 \mathrm{c}$ \\
\hline 20 & 87 & 130 & 22 & 0 & $79 c$ \\
\hline Total & 1,683 & 3,797 & 4,149 & 0 & \\
\hline \multicolumn{6}{|c|}{ Chaoboridae } \\
\hline June 18 & 0 & 0 & 9,594 & 37,293 & $23,444 \mathrm{a}$ \\
\hline 24 & 0 & 0 & 6,708 & 29,214 & $17,961 \mathrm{~b}$ \\
\hline July 2 & 0 & 0 & 6,853 & 17,601 & $12,227 \mathrm{c}$ \\
\hline 9 & 0 & 0 & 2,157 & 11,686 & $6,921 \mathrm{de}$ \\
\hline 16 & 0 & 0 & 2,200 & 14,788 & $8,494 \mathrm{~cd}$ \\
\hline 23 & 0 & 0 & 3,852 & 13,417 & $8,634 \mathrm{~cd}$ \\
\hline 30 & 0 & 0 & 815 & 17,240 & $9,027 \mathrm{~cd}$ \\
\hline Aug. 6 & 0 & 0 & 1,320 & 6,276 & 3,798 de \\
\hline 13 & 0 & 0 & 1,313 & 5,526 & 3,419 de \\
\hline 20 & 0 & 0 & 1,789 & 3,116 & $2,453 \mathrm{e}$ \\
\hline Total & 0 & 0 & 36,601 & 156,157 & \\
\hline
\end{tabular}

aData transformed to $(X+1)$

bAny 2 means followed by the same letter do not differ significantly as determined by Duncan's multiple range test at the $1 \%$ level of probability. 
Matheny and Heinrichs, Annals of the Entomological Society of America 63 (1970)

Acknowledgment - We are grateful to Dr. S. E. Neff, University of Louisville, for identifying the Chironomidae.

\section{References Cited}

Dineen, C. F. 1953. An ecological study of a Minnesota pond. Amer. Midland Natur. 50(2): 349-76.

Eggleton, F. E. 1934. A comparative study of the benthic fauna of four northern Michigan lakes. Pap. Mich. Acad. Sci. Arts Lett. 20: 609-34.

Schultz, V. B. 1952. A limnological study of an Ohio farm pond. Ohio J. Sci. 52(5): 267-85.

Wallen, J. E. 1955. Some limnological considerations in the productivity of Oklahoma farm ponds. J. Wildlife Manage. 19: 450-62.

Welch, P. S. 1948. Limnological Methods. Blakiston Co., Philadelphia. 381 p. 